\title{
Ravitsevaa ruokaa huokeaan hintaan - Carl Tigerstedt suomalaisen kansanravitsemuksen edistäjänä
}

Suomalaisen ravitsemustutkimuksen eräs merkittävä ajankohta on 1800-1900-lukujen vaihde. Tuolloin luotiin pohja ravinnon ja terveyden välisiä yhteyksiä käsittävälle tutkimukselle. Tutkimusperinteen käynnistäjä oli Helsingin yliopiston fysiologian professori Robert Tigerstedt (18531923). (1-3.) Ensimmäisiä kansanravitsemustutkimuksia teki hänen poikansa Carl Tigerstedt (18821930).

Carl Tigerstedt oli koulutukseltaan fysiologi ja hänen lääketieteen väitöskirjansa Helsingin yliopistossa käsitteli verenkiertofysiologiaa. Ravitsemukseen liittyvissä kysymyksissä hän kiinnostui erityisesti ruoankäytön ja sosioekonomisten tekijöiden, kuten ammatin ja varallisuuden välisestä yhteydestä. Hänen päätyönsä ravitsemustieteen alalla, Untersuchung über die Nahrungszuführ des Menschen in ihrer Abhängigkeit von Alter, Geschlecht und Beruf (4), käsitteli eteläsuomalaisen maalaisväestön ruoankäyttöä. Ensimmäinen maailmansota (1914-1918) suuntasi Tigerstedtin toiminnan ja tutkimuksen entistä vahvemmin väestön ravinnonsaantiin ja ruokahuoltoon liittyviin kysymyksiin. Isänsä jälkeen, vuodesta 1920 lähtien, hän toimi fysiologian professorin virassa 1930 tapahtuneeseen varhaiseen kuolemaansa saakka. (5.)

Carl Tigerstedtin elämäntyötä lääketieteen ja fysiologian tutkijana on kuvattu matrikkeleissa, muistokirjoituksissa ja katsauksissa (5-9). Elämäkertaa hänestä ei ole kirjoitettu eikä hänen muistiinpanojaan tai muistelmiaan ole käytettävissä. Helsingin yliopiston arkistossa Carl Tigerstedtiä koskeva aineisto sisältää etenkin opetukseen liittyviä asiakirjoja.

Tässä puheenvuorossa tarkastelen Carl Tigerstedtin toimintaa kansanravitsemuksen näkökulmasta ja tuon esiin hänen merkitystään laitos- ruokailun kehittymiselle ja väestön neuvonnalle. Kuva Tigerstedtin toiminnasta perustuu hänen julkaisuihinsa ja lehtiartikkeleihin sekä aihepiiriä käsittelevään muuhun kirjallisuuteen.

\section{MAAILMANSODAN SYNNYTTÄMÄT RAVITSEMUSKYYYMYKSET}

Ensimmäinen maailmansota (1914-1918) vaikeutti Suomen elintarvikehuoltoa ja johti kulutuksen säännöstelyyn. Vuonna 1917 alkanut viljan ja viljavalmisteiden säännöstely ulottui koko maahan, mutta muita elintarvikkeita säännösteltiin pääasiassa vain asutuskeskuksissa. Pulaa ja niukkuutta oli heikosti omavaraisilla alueilla Itä- ja Pohjois-Suomessa sekä kaupunki- ja taajamaalueiden kotitalouksilla. $(10,11$.) Poikkeukselliset olot heikensivät ruoan turvallisuutta, ja terveydellistä haittaa saattoivat aiheuttaa myös viljan korvikkeina käytetyt raaka-aineet. Elintarvikkeiden hintojen nousu, niin sanottu kallis aika, vaikeutti etenkin vähävaraisen väestön toimeentuloa. (11.)

Senaatin perustaman valtion kotitaloustoimikunnan (1917-1921) tehtävänä oli valistaa väestöä elintarvikkeiden käytössä ja helpottaa elintarvikepulaa. Carl Tigerstedt nimitettiin toimikunnan ravintofysiologiksi, ja hän oli siinä tehtävässä lähes koko toimikunnan työskentelyajan. Toimikunta järjesti mittavaa neuvojatoimintaa, teki valistusaineistoa ja antoi elintarvikeviranomaisille lausuntoja esimerkiksi aiemmin vähäisessä määrin käytetyistä raaka-aineista ja niiden käyttötavoista. (11.) Tigerstedtin toimikunnan nimissä laatimat julkaisut käsittelivät hätäleipää, ruokavastikkeiden ravintoarvoa ja ruoan hintaa (12-15).

Lääketieteellisen koulutuksen saaneena ja ihmisen ravinnontarpeen asiantuntijana hän otti voimakkaasti kantaa myös elintarvikkeiden säännöstelyä koskeneisiin päätöksiin ja niissä havait- 
semiinsa epäkohtiin (16). Syksyllä 1918 hän arvioi esimerkiksi kevyttä työtä tekevän helsinkiläismiehen saavan säännöstelyn alaisista elintarvikkeista vain neljäsosan energiantarpeestaan. Ruokavalion täydentäminen säännöstelyn piiriin kuulumattomilla elintarvikkeilla, kuten kalalla ja kasviksilla, ei kaikille ollut taloudellisesti mahdollista. Tigerstedt vetosi valtiovaltaan, että se tekisi kaiken mahdollisen elintarvikehintojen nousun estämiseksi. $(11,17$.) Säännöstelyyn liittyneet ratkaisut vaikeuttivat myös lääkärien työtä ja heidän mahdollisuutensa potilaiden ruokavaliohoidon järjestämiseksi olivat vähäiset. Lääkäreillä ei ollut yhtenäisiä ohjeita eri sairauksien oikeuttamiin lisäannoksiin eikä ruokavaliohoidon kestoon. Lopullisen päätöksen sairasannoksista tekivät paikalliset elintarvikelautakunnat, joissa lääketieteellinen asiantuntemus puuttui usein täysin. Tigerstedt oli osaltaan vaikuttamassa siihen, että säännöstelynalaisten elintarvikkeiden annoksista laadittiin sittemmin yksityiskohtaiset ohjeet potilashoitoa varten. (11.) Sodan jälkeen hän oli mukana myös komiteassa, joka suunnitteli Yhdysvalloista saadun ruoka-avun oikeudenmukaista jakelua lapsiperheille. (18.)

Koska viljan maahantuonti vaikeutui sodan myötä, sitä korvaavien raaka-aineiden tarve oli suuri. Helsingin yliopiston fysiologian laitoksella Tigerstedt selvitti luonnontuotteiden, kuten jäkälän, olkijauhojen, pellavansiementen, petun ja selluloosan koostumusta ja hyväksikäyttöä elimistössä. Viljaa korvaavan raaka-aineen oli Tigerstedtin mielestä täytettävä kaksi ehtoa: sitä on oltava riittävästi saatavilla ja sitä on kyettävä nauttimaan niin paljon, että huomattava osa energiantarpeesta tulee tyydytetyksi. Syksyllä 1917 hänen tekemänsä tutkimukset osoittivat muun muassa, että senaatin kovasti edistämä asia, jäkälän käyttäminen leipäviljan korvikkeena, oli hyödytöntä; elimistö ei pystynyt käyttämään jäkälää hyväkseen. Sitä vastoin, petun Tigerstedt totesi erinomaiseksi viljan korvikkeeksi. (11.) Tigerstedtin tutkimustulokset olivat tieteellisten julkaisujen (19-22) lisäksi esillä väestölle suunnatussa neuvonta-aineistossa, $(12,14)$ ja niihin viitattiin sekä valtakunnallisissa että paikallisissa sanomalehdissä (23). Viljaa korvaavat raaka-aineet olivat esillä myös marraskuussa 1918 Helsingissä pidetyssä valtakunnallisessa Säilyke- ja vastikenäyttelyssä (24). Vastikkeita ja korvikkeita käsittävä kokoelma, jonka rakentamisessa Carl
Tigerstedtillä lienee ollut merkittävä osuus, sijoitettiin sittemmin osaksi Helsingissä toiminutta Työsuojelunäyttelyä (25). ${ }^{1}$ Luonnonkasvien, kuten jäkälän, merkitys tuli Suomessa arvioitavaksi myös pari vuosikymmentä myöhemmin, toisen maailmansodan elintarvikekysymyksiä pohdittaessa $(26,27)$. Tigerstedtin tutkimuksiin palattiin vielä 1970-luvulla, kun Maanpuolustuksen tieteellinen neuvottelukunta (MATINE) selvitti luonnontuotteiden merkitystä poikkeuksellisten olojen elintarvikehuollossa (28).

\section{KALLIS AIKA JA RAVINNON ARVO}

Ravitsemustieteen ajankohtaisia kysymyksiä 1800 luvun lopulla olivat proteiinin, rasvan ja hiilihydraattien merkitys ja niiden osuudet ruokavaliossa. Saksalaisen kemistin Justus von Liebigin (18031873) näkemys etenkin proteiinin erityisyydestä levisi laajalle (29). Näkemyksessä korostui eläinproteiini, sillä sen hyväksikäyttö oli todettu kasviproteiinia paremmaksi. Liebigin mukaan liha oli ruokavalion tärkein raaka-aine, ja tämän näkemyksen kannattajat eri puolilla Eurooppaa alkoivat väestön neuvonnassa korostaa lihan osuutta ruokavaliossa (30,31). Liha oli kuitenkin kallista ja useimmiten vähävaraisen väestön saavuttamattomissa. Saksassa vähävaraisten mahdollisuutta saada riittävästi hyvänlaatuista proteiinia ryhdyttiin edistämään muun muassa teollisin valmistein. Tunnetuin niistä lienee Liebigin 1865 kehittämä lihauute, Liebigs meat extract. $(32,33$.)

Näkemyksen proteiinin keskeisyydestä omaksui pohjoismaissa Uppsalan yliopiston lääketieteen ja kemian professori August Almén (18331903). Eläinproteiinin ohella Almén korosti rasvan merkitystä ruokavaliossa - Ät mera kött, Ät mera fett. (31.) Myös hän tarkasteli ravitsemuskysymystä vähävaraisen väestön ruokatottumusten ja taloudellisten mahdollisuuksien näkökulmasta. Saksalaistutkijoiden tavoin hän laati luetteloja, joissa ruoka-aineet esitettiin niiden ravintoarvon ja hinnan välisen suhteen mukaan. Ruoka-aineen edullisuus ei siten perustunut yksinomaan sen ostohintaan, vaan sen ravintoainekoostumuksen ja hinnan suhteeseen. Mikäli lihaan ei ollut varaa, luettelon tietoja hyödyntäen vähävarainenkin saattoi koostaa riittävästi proteiinia ja rasvaa sisältävän ruokavalion. Kasviksia ja hedelmiä Almén ei monen muun tavoin pitänyt ravitsemuksen kannalta tärkeinä. $(30,34$.) 
Saksalaiset ja ruotsalaiset näkemykset heijastuivat osin myös Suomeen. Carl Tigerstedt toi sekä julkaisuissaan $(13,15,17,35,36)$ että esitelmissään ${ }^{2}$ esiin ruoka-aineiden koostumusta suhteessa niiden hintaan. Aihepiiristä muodostuikin Tigerstedtin neuvonnan keskeinen teema useiden vuosien ajaksi. Tigerstedtin mielestä ruoan koostumuksen ja hinnan suhdetta arvioitaessa olennaisinta oli kuitenkin ruoan tuottama energia, ei niinkään proteiini. Väestön neuvonnassa käyttämällään termillä ravintoarvo hän tarkoitti ruoan energiaa, kaloriaa," - - ravintoaineiden [ruoka-aineiden] $]^{3}$ kykyä kehittää ruumiissa lämpöä.” Tigerstedtin mielestä perheenäitien tulisi, kaikesta kiireestä ja suuresta työmäärästä huolimatta, opetella arvioimaan ruoan edullisuutta. Heidän tulisi siis osata laskea, mitä ruoka maksaa suhteessa sen sisältämään energiaan. (35.)

"- - Tähän saakka emme ole tottuneet arvostelemaan [ruoka-aineita] tällä tavoin, ja se ehkä näyttääkin ensi silmäyksellä epäilyttävältä ja vaivalloiselta, mutta se on todellisuudessa oikea keino, jonka avulla todella pääsemme selville, kuinka meidän on säästettävä. - - Se ravintoaine [ruoka-aine], joka on buokeabintainen 1000 kalorialta, on huokea ravintoai$n e$-- . (35)

Säästäväisyyttä ja ruoanvalintaa valotetaan käytännönläheisesti Ingrid Graaen ja Tigerstedtin oppaassa Kalliin ajan ruokatalousohjeita erikoisesti huomioon ottaen tärkeimpien ruoka-aineittemme ravintoarvon (1916). Teoksessa ohjeistetaan edullisten ateriakokonaisuuksien suunnitteluun, ruoanvalintaan ja -valmistukseen. Laskelmien taustalla olivat ruoka-aineiden koostumustiedot, pääosin Saksassa tehdyt analyysit, joita suomenkielisessä kirjallisuudessa oli alettu esittää 1890-luvun lopulta lähtien. Graaen ja Tigerstedtin julkaisussa, lentokirjasessa, on noin 70 ruokaainetta, joiden hinta on laskettu suhteessa niiden energiaan. Edullisimpia silloisen hintatason mukaan tarkasteltuina olivat ruisjauhot, ruisleipä ja perunat. Lihaa neuvotaan korvaamaan palkokasveilla, ja ruokavalioon vaihtelua tuovia kasviksia ja hedelmiä suositellaan hankittavan ja säilöttävän silloin, kun ne ovat edullisimmillaan. ${ }^{4}$ (35.) Tigerstedt jatkoi ruoan koostumuksen, ravintoarvon ja hintojen yksityiskohtaista käsittelyä muun muassa suurelle yleisölle suunnatussa julkaisussaan Halpabintainen ruoka (1923). Vaikka Tigerstedtin näkemyksessä korostui energia, hän toteaa elimistön tarvitsevan hiilihydraatteja, munanvalkuaisaineita ${ }^{5}$ ja rasvaa sekä eräitä kivennäisaineita ja "kokoonpanoltaan toistaiseksi meille tuntemattomia aineita n.s. vitamiineja". (15) Teoksen ensimmäinen painos myytiin nopeasti loppuun ja uutta painosta täydennettiin etenkin vitamiinien osalta (37).

Ruoan koostumuksen ja hintojen tarkastelu liittyi vuosisadan alusta lähtien esillä olleeseen kysymykseen toimeentulosta, ruokavaliosta ja työtehosta. Vähävaraisissa kotitalouksissa ravinnon osuus kokonaismenoista oli suuri, ja etenkin perheenäideiltä odotettiin säästäväisyyttä. (38, 39.) Ammattientarkastaja Vera Hjeltin kaupunkien ammattityöläisten toimeentuloa koskeneen tutkimuksen (1908-1909) mukaan ruoan osuus kokonaismenoista oli keskimäärin 55 prosenttia, vaihdellen 50 prosentista 74 prosenttiiin (40). Ensimmäisen maailmansodan aiheuttama hintojen nousu vaikeutti monien toimeentuloa entisestään.

Laskelmia elintarvikkeiden ravintoarvosta, energiasta suhteessa niiden hintaan, alettiin vuodesta 1924 lähtien julkaista Sosialisessa Aikakauskirjassa kuukausittain. Ravitsemusasiantuntijana tässäkin oli Tigerstedt. (41.) Aihe oli hänen toimestaan näyttävästi esillä myös Helsingissä pidetyillä Suomen ensimmäisillä elintarvikealan messuilla, Ravinto- ja nautintoainemessuilla, syksyllä 1926. Niin sanotuksi ravintopöydäksi kutsuttu ruoan koostumusta ja hintaa havainnollistava ja opetuksellisessa mielessä rakennettu messuosasto herätti yleisössä suurta mielenkiintoa. Näyttelypöydällä oli esillä lähes sata elintarviketta. Kutakin niistä oli $500 \mathrm{kcal}$ vastaava määrä, joten elintarvikkeiden paino vaihteli muutamista kymmenistä grammoista muutamaan kiloon. (42.) Kokoelmasta tuli merkittävä ravitsemusvalistusaineisto useiden vuosikymmenten ajaksi. Messujen jälkeen se oli 1960-luvulle asti osa Työsuojelunäyttelyn Ihminen ja ravinto -osastoa. Yleisön toiveiden mukaisesti se päätyi nähtäväksi myös muualle Suomeen, kun Työsuojelunäyttely kiersi useilla maaseutupaikkakunnilla vuosina 19321938. (25.) 


\section{SUUNNITELMIA LAITOSRUOKAILUUN: RAVITSEVAA, EDULLISTA JA VAIHTELEVAA}

Laitosten ruokailun järjestämiseen Carl Tigerstedt perehtyi ensi kerran työuransa alussa osallistuessaan vankilaruokailua kartoittaneen selvityksen ja sen pohjalta tehdyn mietinnön laatimiseen. Selvityksessään Tigerstedt muun muassa vertasi suomalaista vankilaruokaa naapurimaiden vastaavaan ja totesi Suomelle ja Venäjälle olevan Ruotsiin ja Norjaan verrattuna yhteistä viljavalmisteiden runsaus ja kasvisten vähäisyys. (43, 44, 55.) Sekä Robert että Carl Tigerstedtin asiantuntemusta tarvittiin myös sisällissodan seurauksena perustettujen vankileirien ravitsemuskysymyksissä kesällä 1918. He kiinnittivät huomiota vankiruoan energiamäärään ja koostumukseen, tekivät esityksiä ruokailun järjestämisestä sekä ruoanvalmistusta koskevista käytännön yksityiskohdista ja edistivät vankien mahdollisuutta saada omaisten toimittamaa ruokaa. (46.) Tiettävästi ensimmäisen vankileirioloja selostavan raporttinsa Carl Tigerstedt laati jo toukokuussa 1918 Suomenlinnasta. Kesällä hän teki tarkastusmatkoja useisiin Etelä-Suomen vankileireihin ja toi seikkaperäisesti esiin niissä havaitsemiaan puutteita. Myöhemmin syksyllä hän laati vankilalaitokselle ehdotuksen vankien ja henkilökunnan ruokailun järjestämisestä. (47.)

Laitosruokailun kehittämisestä tuli sittemmin Carl Tigerstedtin koko työuran kestänyt ja eri väestöryhmiä koskettanut tehtäväalue. Suunnittelun lähtökohtina hänellä olivat ruoan ravitsevuus, edullisuus ja vaihtelevuus. Vankilaruokailun ohella varhaisimpia oli vuoden 1917 suunnitelma sairaaloiden ruokajärjestykseksi, jonka asiantuntijaryhmässä Tigerstedt oli. Edellinen suunnitelma oli valmistunut vuosisadan alussa (48), mutta uudelleenarviointi oli tarpeen sodan aiheuttaman säännöstelyn ja hintojen nousun takia. Elintarvikepula ulottui kaikille yhteiskunnan alueille, ja sotaan varautumattomalle sairaalalaitokselle etenkin viljan saanti tuotti ongelmia. Väliaikaiseksi tarkoitettu suunnitelma, jossa oli huomioitu muun muassa eri potilas- ja henkilöstöryhmien erilainen energiatarve, oli useissa sairaaloissa voimassa vielä 1920-luvun alussa. (11.)

Ruokahuollon järjestäminen tuli myös pohdittavaksi, kun juuri itsenäistyneen Suomen puolustusvoimia vuonna 1918 perustettiin. Sen lisäksi, että Robert ja Carl Tigerstedt osallistuivat ravintofysiologeina muonituksen periaattei- ta pohtineen komitean työhön, he paneutuivat muonituksen käytännön toteutukseen. Heidän suunnittelemansa, ohjaamansa ja valvomansa ensimmäiset sotilaskeittokurssit pidettiin keväällä 1920. Kursseilta saatujen kokemusten myötä uusittiin Sotilaskeittokirja, joka sisälsi myös ehdotuksen ruokalistasta aterioita ja annoksia kohti laskettuine energiamäärineen. (49.) Carl Tigerstedt oli uusimassa myös vuoden 1928 muonitussuunnitelmaa (50).

Sen lisäksi, että Tigerstedt tiesi eri-ikäisten ja eri väestöryhmien ravinnontarpeeseen liittyvät yksityiskohdat, hän näyttää tunteneen ruokaan liittyvät tunneperäiset, sosiaaliset ja kulttuuriset merkitykset. Kunnalliskodeille laatimassaan suunnitelmassa (51) Carl Tigerstedt kiinnitti tavanomaisten seikkojen ohella huomiota kolmeen ruoka-aineeseen; kahviin, margariiniin ja maitoon. Kunnalliskodeissa asuvien taustaan ja heidän viihtyvyyteensä viitaten hän totesi, "- - kahvilla on ihmeellinen kyky saattaa meidät näkemään elämä valoisampana, ja se on maassamme useinkin köyhän miltei ainoa ilo. Kahvin poistaminen kunnalliskotien ruokajärjestyksestä tai sen antaminen vain kerran viikossa olisi tällaisissa olosuhteissa mielestäni liiallista säästäväisyyttä. Kahvin ei suinkaan tarvitse olla parasta lajia - -." Margariinia hän suositteli voin sijaan ja kuorittu maito sopi ravitsevuutensa ja edullisuutensa vuoksi korvaamaan kuorimaton maito myös kunnalliskodeissa. Vaikka asukkaiden erilainen ravinnontarve oli suunnitelmassa otettu muilta osin huomioon, kahvia - nautintoainetta - Tigerstedt ohjeisti annettavan kaikille yhtä paljon. Sama koski margariinia ja voita, joita Tigerstedt piti ruoka-aineina, mutta kahvin tavoin myös nautintoaineina. Kunnalliskoteihin laadittu suunnitelma näyttää herättäneen arvostelua ja siitä keskusteltiin muun muassa sanomalehdissä. Sen lisäksi, että näissä kommenteissa kuntien halua tai mahdollisuutta suunnitelman noudattamiseen epäiltiin, sitä pidettiin vaihtelevuuden ja annosten koon suhteen vankiloiden ja kuritushuoneiden suunnitelmaa kehnompana. Tigerstedt ei nähnyt arvostelulle perusteita ja totesi, että myös vankilaruoan on oltava riittävää eikä sen määrää tai laatua voi käyttää rangaistuskeinona. (52.) Näkemys ruoasta rangaistuskeinona ei tuohon aikaan ollut outo. Vankilaruokailun historiaa selvittäneen Kyllin mukaan vankien ruokavaliota oli ollut kurinpidollisista 
syistä mahdollista rajoittaa Suomessa vielä 1900luvun alussa, siitäkin huolimatta, että niin sanotusta vesileipävankeudesta oli luovuttu jo 1890luvulla. (45.)

Tigerstedtin vuonna 1929 laatimaa kouluruokailusuunnitelmaa voidaan pitää ensimmäisenä koko maan kattaneena esityksenä ruokailun järjestämiseksi (53). 1900-luvun alussa kouluruokailu oli Suomessa puutteellisesti toteutettu eikä useimmissa kunnissa sitä ollut järjestetty lainkaan (11). Oppivelvollisuuden voimaantulon jälkeen (1921) vastuu järjestelystä tuli kunnille. Mannerheimin Lastensuojeluliitto oli kouluruokailuasiassa aktiivinen, ja sen koulukeittolakomitea vaati keittolan perustamista jokaiseen kansakouluun (53). Kouluruokailusuunnitelman (54), samoin kuin ruokavalio-ohjeet eri-ikäisille lapsille ja raskaana oleville naisille, laati koulukeittolakomitean silloinen puheenjohtaja Tigerstedt. Hänen mielestään kaikkien lasten on varallisuudesta riippumatta saatava lämmin, ravitseva ja maksuton ateria koulupäivänä, sillä "rikkaankin kodin lapsi jää huolimattomuudesta tai jonkun muun syyn takia puutteellisesti ravituksi” (55). Seikkaperäisesti laaditussa suunnitelmassa on kuntien erilaisten toteuttamismahdollisuuksien lisäksi huomioitu aterioiden energiamäärä, kustannukset sekä ruoanvalmistukseen ja -jakeluun liittyvät yksityiskohdat astioiden ja aterimien laatua myöten. Kului kuitenkin parikymmentä vuotta ennen kuin kouluruokailua koskeva asia saatiin Suomessa päätökseen, ja maksuton kouluateria oli mahdollinen kaikille kansakoululaisille. (56.)

Usean vuoden ajan Tigerstedt osallistui Helsingin kaupungin kunnallisen ruokahuollon kehittämiseen, ensi vaiheessa erilaisissa komitea- ja lautakuntatehtävissä. Hän oli keskeinen henkilö järjestettäessä kaupungin ruokahuoltoa ensimmäisen maailmansodan aiheuttaman elintarvikekriisin aikana. Ensimmäiset kunnalliset kansankeittolat, soppakeittiöt, perustettiin Helsinkiin syksyllä 1917 elintarvikepulan lieventämiseksi ja vähävaraisten tueksi. Tuon toiminnan pohjalta sittemmin perustetun keskuskeittolan toimitusjohtajana Tigerstedt toimi muiden tehtäviensä ohella lähes koko 1920-luvun. Suuressa mitassa toimiva kunnallinen ruokahuolto oli tuolloin uutta, ja sillä oli epäilemättä sekä terveydellistä että taloudellista vaikutusta. Keskuskeittolan toiminnasta kertovissa kuvauksissa todetaan muun muassa, että viikon ruokalistat hyväksyttiin käyttöön vasta sitten, kun toimitusjohtaja oli laskenut ruokien energiasisällön. Lääkärintodistuksella oli mahdollisuus saada "dieettiruokia” (57). Terveellistä ruokaa tarjoavan paikan maineessa olleesta keskuskeittolasta käytettiin johtajansa mukaan myös nimeä "Kallen kuppila” (58).

\section{KANSAN RAVINNON TUTKIMINEN}

Suomalaisia ruoka-aineiden koostumustietoja oli 1900-luvun alussa käytettävissä niukasti $(59,48)$. Saksalaisen Königin (60) ja ruotsalaisen Alménin (61) julkaisut, samoin kuin eräät amerikkalaiset (62) koostumustiedot, olivat perustana niille tutkimuksille, joita Carl Tigerstedtin ohella teki Sigfrid Sundström (63-65). Ruoankäyttötutkimusten myötä elintarvikeanalytiikka voimistui ja kehittyi Helsingin yliopiston maatalousekonomian laboratoriossa, kotieläintieteen laitoksella sekä Robert Tigerstedtin johtamalla fysiologian laitoksella $(59,66,67)$.

Carl Tigerstedtin kokoama Ruoka-aineittemme eri aineksia ja ravintoarvoa osoittava taulukko julkaistiin 1920 (68). Taulukossa esitetään 60 ruoka-aineen energia-, proteiini-, rasva- ja hiilihydraattimäärät kiloa kohti. Siitä ilmenee myös, mikä määrä kutakin ruoka-ainetta vastaa 1000 kaloria $^{6}$. Koostumustietojen lähteitä julkaisussa ei mainita. Taulukko oli laajasti käytössä, ja se oli lähtökohtana, kun Maatalousseurojen Keskusliitto 1930-luvulla kokosi uutta ruoka-ainetaulukkoa tutkimusta ja neuvontatyötä varten. $(69,70)$.

Vuosisadan alun ensimmäisten ruoankäyttötutkimusten mukaan miesten ja lasten energiansaanti oli keskimäärin riittävää, mutta naisilla tarpeeseen nähden niukka energiansaanti oli yleistä. Tigerstedtin tutkimus (1916) osoitti myös, että sosioekonomisilla tekijöillä oli vaikutusta ruokavalion laatuun: vähävaraisissa perheissä hiilihydraattien osuus oli keskimääräistä isompi. Ruokavalio oli yksitoikkoinen ja kahvin osuus suuri. Maaseudulla ruokavalio koostui pääasiassa vilja- ja maitovalmisteista, perunoista ja joistakin kasviksista. Lihaa, kalaa ja kananmunaa käytettiin vähän. Kaupunkiväestön ruokavaliosta oli vielä niukasti tietoa, mutta Tigerstedt kuvasi sen koostuvan "kuivasta ruoasta" eli kahvista ja leivästä, mikä ei taloudellisesti eikä terveyden kannalta ollut järkevää. Tuo "aliarvoinen" ruo- 
kavalio johtui hänen mielestään heikoista ruoanvalmistustaidoista (71). Taito ja ruoanlaittajan "hyvä tahto" olivat hänen mukaansa edellytys sille, että ruoka on vaihtelevaa ja hyvänmakuista (51).

"Kun on kysymys kotona valmistetusta ruoasta, voimme olla vakuutettuja siitä, että ruoassa on kaikkia ruumiillemme välttämättömiä ravintoaineita, olivatpa ne mitä lajia tahansa, kunhan ruoka vain on maukasta ja vaibtelevaa, ja kunhan sitä on niin paljon saatavissa, että kukin saa syödä itsensä kylläiseksi.” (72)

Eräs syy siihen, miksi suomalaiset olivat "keittotaidon ja ruokajärjestyksen puolesta paljon alemmalla tasolla kuin läntinen naapurikansamme" oli Tigerstedtin mielestä ennakkoluuloisuus uusia ruoka-aineita ja ruokalajeja kohtaan. Ennakkoluulot ilmenivät hänen mukaansa myös ajankohdan uutuuteen, margariiniin, suhtautumisessa. Tigerstedt oli itse siirtynyt margariinin käyttäjäksi ja kehotti siihen muitakin (72-74) - ja tätä margariiniteollisuus myös hyödynsi lehtimainoksissaan (75). Voita selvästi edullisempana, mutta yhtä ravitsevana, margariini sopi Tigerstedtin mielestä erityisesti vähävaraisen väestön ruokavalioon $(36,74)$. Työväestön ja vähävaraisen maaseutuväestön keskuudessa, eli siinä väestönosassa, jolle tuote oli edullisuutensa vuoksi suunnattu, margariiniin suhtauduttiin kuitenkin epäluuloisesti. Sen pelättiin aiheuttavan terveyshaittaa, kuten vatsavaivoja ja työkyvyn heikkenemistä, ja sen ruoanvalmistusominaisuuksia pidettiin huonoina. $(76,77)$. Edelleenkin, sata vuotta myöhemmin, ravinnon rasvojen laadusta ja määrästä keskustellaan julkisuudessa vilkkaasti. Riittävään energian saantiin ja osin maatalous- ja kauppapoliittisiin näkökohtiin painottuneen keskustelun sijasta painopiste on 1950-luvulta lähtien ollut rasvojen terveysvaikutuksissa. $(42,78,79$.) Margariini ylitti voin kulutuksen ensimmäisen kerran vuonna 1988 (80).

Suomalaisten ruokavalion piirteitä ja puutteita Tigerstedt toi esiin myös suurelle yleisölle suunnatuissa artikkeleissaan. Eräs julkaisutaho oli 1922 perustettu Kotiliesi, jonka vakituiseen avustajakuntaan hän kuului. Ruoan ravintoarvon ja hinnan näkökulmasta hän vertaili esimerkiksi puuro- ja kahviaamiaista, arvioi kansan keskuudessa halveksittujen raaka-aineiden, kuten sisäelinten ja hevosenlihan koostumusta, ja antoi ohjeita lasten ravinnosta; enemmän puuroja, vellejä, kuorimatonta maitoa, kuivaa leipää ja vähemmän kahvia. (36,73,81-83.) Uusinta tutkimustietoa, vitamiinien lähteitä ja tehtäviä, hän selostaa artikkeleissaan yksityiskohtaisesti (8486). Tigerstedtin ymmärrys ruoanvalmistukseen liittyvistä käytännön seikoista ja suomalaisen ruokakulttuurin alueellisista piirteistä ilmenee puolestaan hänen asiantuntijakommenteissaan lehden järjestämän ruokalistakilpailun yhteydessä (87). Lehdestä välittyy myös Tigerstedtin merkitys kotitalousalalle. Kotilieden toimituskuntaan kuulunut kansanedustaja ja kotitalousalan keskeinen toimija, Hedvig Gebhard, totesi alan saaneen hänestä asiantuntijan, jonka "harrastus yhtyy käytännössä toimivien asianharrastajien arkipäiväiseen raatajatyöhön”. (88.) Tigerstedtin laatima ensimmäinen suomalainen ravinto-opin oppikirja (1927) (72) on epäilemättä ollut kotitalousalan koulutukselle niin ikään arvokas.

Tigerstedtin ja Sundströmin ensimmäiset ravintotutkimukset oli pääosin tehty ilman valtion tukea, ja sota-ajan viljan korvikkeita koskeneisiin tutkimuksiin oli ollut hankittava rahoitus yksityiseltä taholta. Tigerstedt kokikin valtion suhtautuvan asiantuntijuuteen ja ravitsemustutkimukseen väheksyvästi. $(89,71$.) Suomalaistutkijoiden vaatimattomat tutkimusresurssit konkretisoituivat hänelle Yhdysvaltoihin 1929 suuntautuneella kongressimatkalla - - "meillä pitäisi hallitusvallan jo vihdoinkin huomata, että pienen maan maine riippuu siitä, kuinka korkealla ja arvostettua sen tiede on. Meillä tutkimusinnostus on suuri, mutta taloudellisia resursseja vähän.” (90)

” - - Me ravintofysiologit olemme siis tottuneet siihen, että meidän mielipidettämme ei oteta huomioon, kun on kysymys Suomen kansan ravitsemisesta - -”. (89)

\section{CARL TIGERSTEDTIN JÄLJET}

Carl Tigerstedtin toiminta ajoittui vuosikymmenille, joita Suomessa leimasivat vuosisadan vaihteessa voimistunut kaupungistuminen, ensimmäinen maailmansota seurauksineen ja sodan jälkeen alkanut yhteiskunnan kasvun ja modernisoitumisen aika. Ravitsemustieteessä (34) tuota ajanjaksoa kuvataan vaiheena, jolloin tutkimustieto ja 
ymmärrys ravintoaineista, etenkin vitamiineista ja niiden tehtävistä kasvoi ja tarkentui merkittävästi.

Robert Tigerstedtin (1) aloitteesta käynnistyneet ruoankäyttötutkimukset antoivat ensi kerran tietoa suomalaisväestön ravinnonsaannista ja sen riittävyydestä. Tutkimusmetodiikka, jossa kohteena oli ihmisen vapaasti valitsema ravinto eivätkä laboratorio-oloissa valmistetut ruokavaliot, herätti aikalaiskollegoissa sekä kiinnostusta että kritiikkiä. Uusi metodi antoi kuitenkin mahdollisuuden tarkastella ravitsemuksellisia, yhteiskunnallisia ja sosiaalipoliittisia kysymyksiä lähellä toisiaan. (5.) Tutkimusperinne voimistui hitaasti, ja aina 1930-luvulle asti Carl Tigerstedtin ja Sigfrid Sundströmin kansanravintotutkimukset olivat ainoita laajahkoja alan tutkimuksia (70). Niiden ansiosta Suomen kansan ravitsemuksesta on tietoa yli sadan vuoden ajalta.

Carl Tigerstedt oli kantaa ottava, yhteiskunnallisesti aktiivinen ja kiinnostunut erityisesti vähävaraisen väestön toimeentulosta. Ensimmäisen maailmansodan synnyttämiin ravitsemus- ja ruokahuoltokysymyksiin hän paneutui monin tavoin. Tuolloin kertyneelle tutkimustiedolle oli käyttöä elintarvikesäännöstelyä suunniteltaessa ja toteutettaessa seuraavan suursodan yhteydessä. (5.)

Tigerstedtin käytäntöön suuntautunut lähestymistapa ilmenee hänen ruokavalion tarkoituksenmukaisuuteen ja riittävyyteen liittyneissä näkemyksissään. Sen sijaan, että hän olisi korostanut yksittäisen ravintoaineen merkitystä, hän piti tärkeänä ruoanvalintaa, ruokavalion vaihtelevuutta ja käytännön ruoanvalmistustaitoja - seikkoja, joita myös nykyisessä ruokakasvatuksessa korostetaan. Hänen näkemyksensä suositeltavan ruokavalion ominaisuuksista - ravitseva, edullinen ja vaihteleva - välittyivät myös laitosten ruokahuollon suunnitelmiin. Sitä, missä määrin ja miten kauan suunnitelmat eri tahoilla olivat käytössä, ei tässä yhteydessä ollut mahdollista selvittää. Muutoksia laitosruokailun käytäntöihin jouduttiin kaikkialla tekemään viimeistään talvi- ja jatkosodan takia. Nykysuomalaisten arjessa sairaaloiden, vankiloiden ja armeijan keittiöistä alkunsa saanut joukkoruokailu on olennainen osa, ja esimerkiksi henkilöstöravintoloiden ateriatarjonnalla tiedetään olevan merkitystä työikäisen väestön ravinnonsaannille ja terveyden ylläpitämiselle. (91.)
Carl Tigerstedtin elämä päättyi 48-vuotiaana purjehdusonnettomuudessa Porvoon edustalla heinäkuussa 1930. Vain parikymmentä vuotta kestänyt työ väestön ravitsemukseen liittyvissä kysymyksissä oli mittava ja monipuolinen. Toinen maailmansota, nopeat yhteiskunnalliset muutokset ja ravitsemustutkimuksen painopisteiden vaihtuminen lienevät osaltaan vaikuttaneet siihen, että Tigerstedtin toiminta on jäänyt melko vähäiselle huomiolle. Tapaturmaiseen kuolemaansa asti hän oli aktiivinen tutkija ja julkaisija myös erikoistumisalallaan lääketieteessä.

Carl Tigerstedtin professorikauden jälkeen tutkimus Helsingin yliopiston fysiologian laitoksella suuntautui vitamiineihin ja hivenaineisiin. Ravintofysiologinen tutkimus jäi vähemmälle ja painopiste siirtyi lääketieteelliseen kemiaan ja biokemiaan. $(2,67$.$) Robert ja Carl Tigerstedtin$ tutkimustyö ja toiminta olivat eräs tärkeä taustatekijä, kun Helsingin yliopistoon perustettiin 1947 ravintokemian ${ }^{7}$ professuuri (3).

\section{KaIJA RAUTAVIRTA \\ ETT, yliopistonlehtori \\ Helsingin yliopisto \\ Kasvatustieteellinen tiedekunta}

\section{VIITTEET}

1 Näyttelystä on eri yhteyksissä käytetty myös nimiä Työsuojelu(s)- ja huoltonäyttely, Sosiaalimuseo, Yhteiskunnallinen museo, Työsuojelunäyttely - työsuojelun tieto- ja opastuskeskus.

2 Tieteellisten seurojen, yhdistysten, Turun Akatemian luentosarjojen ja kesäkurssien lisäksi Tigerstedt luennoi ja piti esitelmiä mm. Helsingin ruotsinkielisellä työväenopistolla/Stads Arbetarinstituts svenskspråkiga avdelning.

3 1900-luvun alun julkaisuissa termillä ravintoaine tarkoitettiin yleensä ruoka-ainetta.

4 Laskelmat perustuivat Helsingissä 15.1.1916 vallinneeseen hintatasoon.

5 Proteiineja aiemmin tarkoittanut termi, joka perustui kananmunan valkuaisen koostumukseen.

$6 \quad$ Kalorilla tarkoitettiin tuolloin yleensä kilokaloria.

7 1977-2002 ravitsemustieteen, 2003- ravitsemusfysiologian professuuri. 


\section{LÄHTEET}

1 Tigerstedt R. Om undersökning af finske arbetares föda. Finska Läkaresällskapets Handlingar 1903;45:493-501.

2 Räsänen L. Suomalaisen ravitsemustutkimuksen kehityslinjat ja yhteydet yhteiskunta- ja käyttäytymistieteisiin. Sosiaalilääk Aikak 1986;23:104-110.

3 Ahlström A. Finnish nutrition education and research. $50^{\text {th }}$ anniversary of nutrition education at Helsinki University. Scandinavian Journal of Nutrition/Näringsforskning 1997;41:111-116.

4 Tigerstedt C. Untersuchungen über die Nahrungszuführ des Menschen in ihrer Abhängigkeit von Alter, Geschlecht und Beruf. Skand Arch Physiol 1916;34:151-381.

5 Ahlström A, Rautavirta K. Fysiologit Robert ja Carl Tigerstedt Suomen kansanravitsemuksen edistäjinä. Hippokrates 2013;30:49-64.

6 Rancken D. Carl Tigerstedt. Minnesteckning. Finska Läkaresällskapets Handlingar 1930;72:955-961.

7 Renquist Y. Carl Tigerstedt. Duodecim 1930;11:941-943.

8 Heikinheimo I. Carl Tigerstedt. Kirjassa Heikinheimo I. (toim.) Suomen elämäkerrasto. Porvoo: WSOY; 1955.

9 Autio V-M. Carl Tigerstedt. Kirjassa MäkeläAlitalo A, Klinge M, Litzen A. (toim.) Suomen Kansallisbiografia 9. Helsinki: Suomalaisen Kirjallisuuden Seura; 2007, 785-786.

10 Rantatupa H. Elintarvikehuolto ja -säännöstely Suomessa vuosina 1914-1921. Studia Historica Jyväskyläensia 17. Jyväskylä: Jyväskylän yliopisto; 1979.

doi: 10.1086/ahr/85.2.412

11 Rautavirta K. Petusta pitsaan. Ruokahuollon järjestelyt kriisiaikojen Suomessa. Helsinki: Helsingin yliopisto, maatalous-metsätieteellinen tiedekunta; 2010. http://urn.fi/URN:ISBN:978-952-10-6303-9

12 Tigerstedt C. Hätäleivästä. Valtion kotitaloustoimikunnan lehtisiä n:o 3. Helsinki: Suomen senaatin kirjapaino; 1917.

13 Tigerstedt C. Ruoka-aineittemme ravintoarvo ja hinta. Valtion kotitaloustoimikunnan tiedonantoja 32. Helsinki: Suomen senaatin kirjapaino; 1918.

14 Tigerstedt C. Ruokavastikkeiden ravintoarvo. Valtion kotitaloustoimikunnan lehtisiä n:o 6. Helsinki: Valtioneuvoston kirjapaino; 1919.

15 Tigerstedt C. Halpahintainen ruoka. Valtion kotitaloustoimikunnan lehtisiä n:o 11 . Helsinki: Valtioneuvoston kirjapaino; 1923.

16 Tigerstedt C. Vår livsmedelsfråga. Refererad vid Finska Läkaresällskapets möte den 21 September 1918. Referat I. Finska Läkaresällskapets Handlingar 1918; LX:1-14.

17 Tigerstedt C. Människans näringsbehov och dyrtiden. Schildts revy 1917;2:68-78.

18 Tigerstedt R. Amerikan antama avustus Suomen lapsille. Sosialinen aikakauskirja 1920;14:247267.
19 Tigerstedt C. Jäkälät ihmisravintona. Yliopiston fysioloogisella laitoksella suoritettujen kokeiden tulokset. Hankkijan koetoimintajulkaisuja 1. Helsinki; 1918.

20 Tigerstedt C. Über den Nährwert der Fichten baumrinde beim Menschen. Öfversigt af Finska Vetenskaps-Societetens Förhandlingar 19181919;16:1-26.

21 Tigerstedt C. Nährwert des Heumehls beim Menschen. Öfversigt af Finska VetenskapsSocietetens Förhandlingar 1919;17:1-13.

22 Tigerstedt R, Tigerstedt C. Försök öfver hydrocellulosans näringsvärde. Öfversigt af Finska Vetenskaps-Societetens Förhandlingar 1919;3:157.

23 Esim. Jäkälän arvo ihmisravintona. Wiipuri 15.1.1918; Pellavansiemenen käyttö ihmisravinnoksi. Työmies 27.3.1918; Pettujauhon valmistaminen. Helsingin Sanomat 24.5.1918.

24 Esim. Säilyke- ja vastikenäyttelyn avajaiset. Helsingin Sanomat 18.11.1918.

25 Rautavirta K. Ammattientarkastaja Vera Hjelt ja ravitsemus osana työsuojelua. Sosiaalilääk Aikak 2018;55:60-70. doi: https://doi.org/10.23990/sa.69225

26 Rautavaara T. Mihin kasvimme kelpaavat. Leivän lisänä, ruoan aineksina, mausteina, kahvin ja teen korvikkeina, lääkkeinä, rehuna sekä teknillisiin tarkoituksiin. I osa: kevään ja alkukesän kasveja. Porvoo: WSOY; 1942.

27 Rautavaara T. Mihin kasvimme kelpaavat. Leivän lisänä, ruoan aineksina, mausteina, kahvin ja teen korvikkeina, lääkkeinä, rehuna sekä teknillisiin tarkoituksiin. II osa: kesän ja syksyn kasvit. Porvoo: WSOY; 1943.

28 MATINE, maanpuolustuksen tieteellinen neuvottelukunta, muonitusjaosto. Mahdollisuuksista tukeutua luonnonvaraisiin eläimiin ja kasveihin ravinnonlähteinä. I osa. Tutkimuksen perusteet, yhteenvedot ja päätelmät. Raporttisarja 2/A79. Helsinki: Puolustushallinto; 1979.

29 Carpenter KJ. Short History of Nutritional Science: Part 1 (1785-1885). J Nutr 2003;133: 638-645. https://doi.org/10.1093/jn/133.3.638

30 Hirdman Y. Magfrågan. Mat som mål och medel. Stockholm 1870-1920. Stockholm: Rabén \& Sjögren; 1983.

31 Fjellström C. Drömmen om det goda livet. Livskvalitet och matvanor i ett uppväxande industrisamhälle: Stocka sågverk 1870-1980. Acta Ethnologica Umensia. Stockholm: Almqvist \& Wiksell International; 1990.

32 Finlay MR. Early Marketing of the Theory of Nutrition: The Science and Culture of Liebig's Extract of Meat. Kirjassa Kamminga H, Cunningham A. (toim.) The Science and Culture of Nutrition, 1840-1940. Wellcome Institute Series in the History of Medicine. Amsterdam: Editions Rodopi; 1995, 48-71. https://doi.org/10.1163/9789004418417 
33 Qvarsell R. Maten och vetenskapen. Näringslära, kostvanestudier och socialpolitik, ca 1880-1960. Lychnos, tema: Mat 2005;143-294.

DiVA, id: diva2:253832

34 Carpenter KJ. Short History of Nutritional Science: Part 2 (1885-1912). J Nutr 2003;133: 975-984. https://doi.org/10.1093/jn/133.4.975

35 Graae I, Tigerstedt C. Kalliin ajan ruokatalousohjeita erikoisesti huomioon ottaen tärkeimpien ruoka-aineittemme ravintoarvon. Ajankysymyksiä 13. Porvoo: WSOY; 1916.

36 Tigerstedt C. Ruoka-aineiden ravintoarvo ja hinta. Kotiliesi 1926; 9:253-255.

37 Halpahintainen ruoka. Kotiliesi 1924;21:658.

38 Milles D. Working Capacity and Calorie Consumption: The History of Rational Physical Economy. Kirjassa Kamminga H, Cunningham A. (toim.) The Science and Culture of Nutrition, 1840-1940. Wellcome Institute Series in the History of Medicine. Amsterdam: Editions Rodopi; 1995, 75-95. https://doi.org/10.1163/9789004418417

39 Ahlqvist K. Kulutus, tieto, hallinta: kulutuksen tilastoinnin muutokset Suomessa 1900-luvun Suomessa. Helsinki: Helsingin yliopisto; 2010. http://urn.fi/URN:ISBN:978-952-244-230-7

40 Hjelt V. Ammattityöläisten toimeentuloehdot Suomessa vv. 1908-1909. Suomen yleinen työtilasto XIII. Helsinki: Keisarillisen senaatin kirjapaino; 1912.

41 Elintarvikkeiden keskihinnat koko maassa ja ravintoarvo, lokakuu 1924. Sosialinen Aikakauskirja 1924;11:860-861.

42 Rautavirta K, Ahlström A. Ravitsevaa ja edullista. Suomen ensimmäiset elintarvikemessut 1926. Ennen ja nyt: historian tietosanomat. 5.6.2018. https://www.ennenjanyt.net/2018/06/ ravitsevaa-ja-edullista-suomen-ensimmaisetelintarvikemessut-1926/

43 Tigerstedt C. Undersökning öfver utspisningen i Finlands fängelser enligt uppdrag af Fångvårdsstyrelsen. Helsingfors: Senaten; 1910.

44 Kejserliga Senaten fångvårdsstyrelsen. Betänkande, afgifvet af den kommitteé som den 15 september 1909 tillsatts af Fångvårdsstyrelsen med uppdrag att afgifva utlåtande och förslag rörande utspisningen vid landets fängelser och tvångsuppfostringensanstalter. Helsingfors: Edlundska Bokhandeln; 1911.

45 Kylli R. Vettä ja leipää? Vankilaruoka ja vallankäyttö 1800-luvun lopussa ja 1900-luvun alussa. Historiallinen aikakauskirja 2017;1:3-17. http://urn.fi.libproxy.helsinki.fi/ URN:NBN:fi:ELE-2482487

46 Paavolainen J. Vankileirit Suomessa 1918. Helsinki: Tammi; 1971.

47 Kansallisarkisto, sotavankilaitoksen arkisto; 1918.

48 Ehrström R. Om sjukhuskost särskildt med hänsyn till förhållandena i Finland. Finska Läkaresällskapets Handlingar 1905;3:215-385.
49 Tigerstedt R, Tigerstedt C. Sotilaskeittokirja. Helsinki: Kirjapaino-Oy; 1922.

50 Lindén VF. Helsingin Sanomain toimitukselle "Häpeä". Helsingin Sanomat 23.8.1929.

51 Tigerstedt C. Kunnalliskotien ruokajärjestys. Maalaiskunta 1922;5:89-104.

52 Kuritushuoneiden ja kunnalliskotien ruokajärjestys. Helsingin Sanomat 8.9.1926; Vankiloiden ja kunnalliskotien ruokajärjestyksestä. Helsingin Sanomat 9.9.1926: Vankiloiden ja kunnalliskotien ruokajärjestys. Helsingin Sanomat 15.9.1926.

53 Heydemann I, Ylppö A. Suomen lapsen pitkä marssi. Porvoo: WSOY; 1980.

54 Ehdotus kansakoulujen ruokajärjestykseksi. 1. Suomen Punainen Risti 1929;3: 62-65; Ehdotus kansakoulujen ruokajärjestykseksi. 2. Suomen Punainen Risti 1929;4: 86-88.

55 Tigerstedt C. Kaikkien kansakoululasten on koulussa saatava yksi ravitseva ateria päivässä. Sitä vaatii jo kasvavan polven terve kehitys. Uusi Suomi 3.11.1929.

56 Laki kansakoululaitoksen kustannuksista annetun lain muuttamisesta. SA 637/1943.

57 Impola S, Packalén L. Ruokahetki hyvän mielen tuo. Helsingin kunnallinen elintarvikehuolto 75 vuotta. Helsinki: Helsingin kaupunki ruokapalvelukeskus; 1992.

58 Mäkinen R, Sysiharju A-L. Eteenpäin ja ylöspäin. Hedvig Gebhardin osuus ja toiminta. Keuruu: Otava; 2006.

59 Grönberg J. Våra vanligaste födoämnen i kemiskt och i dietetiskt afseende. Finska Läkaresällskapets Handlingar 1903;45: 443-475.

60 König J. Chemie der menschlichen Nahrungs- und Genussmittel. Berlin; 1880, 1889, 1903, 1904.

61 Almén A. Våra vanligaste näringsmedels sammansättning, näringsvärde, pris och billighet. Stockholm: P.A. Norstedt \& Söner Förlag; 1885; Almén A. Huslig ekonomi och dess tillämpning på utspisningen vid allmänna inrättningar. Stockholm: P.A. Norstedt \& Söner Förlag; 1902.

62 Atwater WO, Woods CD. The Chemical Composition of American Food Materials. Washington: U. S. Department of Agriculture, Office of Experiment Stations; 1896, 1906 https:// www.ars.usda.gov/ARSUserFiles/80400525/Data/ Classics/es028.pdf

63 Sundström S. Några undersökningar af födan i Finland. Finska Läkaresällskapets Handlingar 1905;47: 421-451.

64 Sundström S. Über die Ernährung bei frei gewählter Kost. Skand Arch Physiol 1906;19.

65 Sundström S. Untersuchungen über die Ernährung der Landbevölkerung in Finnland. Väitöskirja. Helsinki: Helsingin yliopisto; 1908.

66 von Wendt G. Ravintomme taloudellinen arvo. Helsinki: Otava; 1916.

67 Lampisjärvi T. Suomalaisen 
ravitsemustutkimuksen historiaa. Pro gradu. Helsinki: Helsingin yliopisto, ravitsemustiede; 1985.

68 Tigerstedt C. Ruoka-aineittemme eri aineksia ja ravintoarvoa osoittava taulukko. Helsinki: Valtion kotitaloustoimikunta; 1920.

69 Maatalousseurojen Keskusliitto. Ruoka-ainetaulukoita. Maatalousseurojen keskusliiton julkaisu N:o 235. Helsinki; 1935.

70 Kansanravitsemuskomitea. Tutkimuksia kansan ravitsemustilan parantamiseksi. Komiteanmietintö N:o 5. Helsinki: Valtioneuvoston kirjapaino; 1940.

71 Tigerstedt C. Kansanravinto. Kirjassa Donner A. (toim.) Suomi: Maa, kansa, valtakunta. II. Helsinki: Otava; 1923, 464-470.

72 Tigerstedt C, Laine K. Ruokatalous I. Ravintooppi. Porvoo: WSOY; 1927.

73 Tigerstedt C. Muutamia halveksittuja ruokaaineita. Kotiliesi 1923;1:8-9.

74 Tigerstedt C. Totuus margariinista. Oulu: S. W. Paasivaara; 1927.

75 Mitä sanoo maamme etevin ravintoaineiden tutkija, Helsingin Yliopiston Fysiologian Professori Carl Tigerstedt meidän margariinistamme ja sen ravintoarvosta? Kotiliesi 1925;2.

76 Pantzar M. Voin ja margariinin julkinen dialogi Suomessa 1923-1987. Sosiaalilääk Aikak 1992;29:146-155.

77 Viinisalo M. Ravintorasvoihin liittyvät intressit

- Rasvakeskustelu ennen II maailmansotaa.

Keskustelualoitteita 5. Helsinki: Kuluttajatutkimuskeskus; 1993.

78 Suojanen A. Suomalaista ravitsemuspolitiikkaa vuosina 1939-1999. Kansanravitsemusongelmat ja niiden ratkaisuehdotusten eteneminen julkisiksi päätöksiksi. Bidrag till kännedom av Finlands natur och folk 157. Helsinki: Suomen tiedeseura; 2003.
79 Syrjäläinen P, Ryynänen T, Heinonen V, ym. Hyvän ja pahan taistelu - ravinnon rasvojen mediajulkisuus Helsingin Sanomissa 2010-2011. Sosiaalilääk Aikak 2016;53:44-57. https://journal. fi/sla/article/view/55931

80 Lahti-Koski M, Rautavirta K. Suomalainen ravitsemus ja sen kehitys. Kirjassa Aro A, Mutanen M, Uusitupa M. (toim.) Ravitsemustiede. 4. uud. p. Helsinki: Duodecim; 2012, 236-255.

81 Tigerstedt C. Keittoruoan merkitys kuivan ruoan rinnalla. Kotiliesi 1928;19:660-661.

82 Tigerstedt C. Kahvi- vai puuroaamiainen? Kotiliesi 1929:5:159-160.

83 Tigerstedt C. Mitä lapset saavat syödä? Kotiliesi 1929;17:695-696.

84 Tigerstedt C. N.s. vitamiinit. Kotiliesi 1923;23:686-689.

85 Tigerstedt C. Vitamiinit I. Kotiliesi 1926;14:399400.

86 Tigerstedt C. Vitamiinit II. Kotiliesi 1926;15:430431.

87 Tigerstedt C. Kotilieden ruokalistakilpailu. Asiantuntijan lausunto. Kotiliesi 1924;9:288-291.

88 Gebhard H. Professori Carl Tigerstedt. Kotiliesi 1930;17:732.

89 Tigerstedt C. Säännöstelyjärjestelmän merkitys ravintokysymyksen kannalta. Kansantaloudellisen yhdistyksen lehti 1921;2:1-8.

90 Med europeiska fysiologer till Amerika. Hufvudstadsbladet 6.9.1929; Amerikassa uhrataan tieteelliseen työhön runsaasti varoja. Helsingin Sanomat 13.9.1929.

91 Raulio S. Lunch eating patterns during working hours and their social and work-related determinants: Study of Finnish employees. Väitöskirja, Helsinki: Helsingin yliopisto. http://urn.fi/URN:ISBN:978-952-245-523-9 